\title{
Export-Oriented Populism: Commodities and Coalitions in Argentina
}

\author{
Neal P. Richardson
}

Published online: 19 December 2008

(C) The Author(s) 2008. This article is published with open access at Springerlink.com

\begin{abstract}
A new form of populism, combining broad-based benefits for urban workers with export promotion, emerged in Argentina under Néstor Kirchner (20032007). This article argues that changes in agricultural production created the conditions for this "export-oriented populism." Historically, Argentina's main exports, beef and wheat, were also the primary consumption goods of urban workers. Scholars such as Guillermo O'Donnell have argued that this linkage increased rural-urban conflict, resulting in shifting coalitions and recurring crises. Today, soybeans have replaced beef and wheat as the country's leading export. Because soybeans are not consumed by the working class, Kirchner could both promote and tax their export, generating fiscal revenue for populist programs while not harming the effective purchasing power of urban workers or provoking a balance-of-payments crisis. Export orientation thus provided the basis for a new variant of Argentine populism. This study offers a new argument within the classic research tradition on the interaction between politics and various types of export growth. It likewise provides an additional basis for arguing that populism, as a form of politics, can arise in diverse economic circumstances. Furthermore, this article contends that, rather than uniformly promoting political stability, the effect of export booms is conditioned by the nature of economic linkages between the export sector and the domestic economy.
\end{abstract}

Keywords Populism $\cdot$ Argentina $\cdot$ Kirchner $\cdot$ Export orientation $\cdot$ Resource wealth . Agriculture

\footnotetext{
Revised version of a paper presented at the XXVII International Congress of the Latin American Studies Association, Montreal, Quebec (September 5-8, 2007). Thanks to Ruth Berins Collier, David Collier, Kent Eaton, Sebastián Etchemendy, Miguel de Figueiredo, Danny Hidalgo, Jody LaPorte, Lindsay Mayka, Rodrigo Zarazaga, participants in the Latin American Politics Seminar at the University of California, Berkeley, and three anonymous reviewers for comments on previous drafts. The author recognizes support of the National Science Foundation Graduate Research Fellowship Program.
}

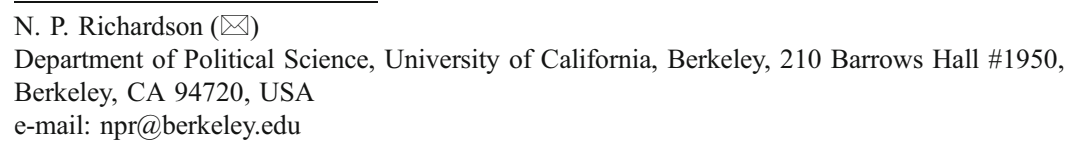




\section{Introduction}

A new variant of populism, combining elements of traditional Latin American populism with export promotion, has emerged in Argentina. The government of Néstor Kirchner (2003-2007) cultivated the support of organized labor and domestic business interests while attacking the "elite," including international creditors and multinational oil corporations. It directed broad benefits to urban workers, supporting real wages through food subsidies and price agreements with merchants. These redistributive programs occurred while the government sustained economic growth and avoided hyperinflationary and balance-of-payments crises. This relative success contrasts sharply with Argentina's historical experience with populism, which was a key player in the cycle of political instability, economic crises, and military coups during the postwar period (O'Donnell 1973; Collier and Collier 1991). How did this new form of populism manage to sustain itself?

I argue that the answer lies not in the urban sector-the traditional focus of research on populism - but in the rural sector. Historically, agricultural commodity production and export exacerbated the instability of populist politics in Argentina. Guillermo O'Donnell (1978) noted that because Argentina's main exports-beef and wheat - were also the primary goods consumed by the working class, economic conflict between rural exporters and the urban masses was direct. Redistribution to urban workers involved restricting exports, thereby increasing the domestic supply of these "wage goods," yet reducing rural income and exacerbating the trade imbalance. Conversely, resolving trade imbalances involved promoting exports, which redistributed away from urban workers by reducing domestic supply of wage goods. In the context of a large, mobilized labor movement, these economic linkages between trade and wage policy led to recurring economic crises and shifting political coalitions.

Since the 1970s, Argentina's rural economic foundations have shifted. Agricultural productivity has dramatically increased, and soybean cultivation has rapidly expanded, replacing beef and wheat as the country's leading export commodity. In recent years, soybeans and their derivatives have generated three times greater export revenue than have beef and wheat products combined. Unlike beef and wheat, soybeans are not consumed domestically; hence, their export has no direct effect on the effective purchasing power of urban workers. The Kirchner government exploited this fact, undervaluing the exchange rate to promote exports, and then taxing the soy exports to subsidize domestic consumption of wage goods, including beef and wheat. This reduced the tension between the goals of increasing urban wages and avoiding financial crisis. Consequently, changes in agricultural production have allowed the linking of export promotion and populism. The resulting system-“export-oriented populism"-eliminates important sources of political and economic instability that had plagued previous incarnations of Argentine populism. Nevertheless, it may also generate new political conflicts.

This article links two burgeoning areas of research in political science and economics, which have focused on (1) the resurgence of leftism and populism in Latin America and (2) the political effects of resource wealth. On the former, the emergence of export-oriented populism confirms that populism-i.e., a multi-class, predominantly urban political coalition featuring a mobilized labor movement - can 
arise in diverse economic circumstances, thereby advancing a recent conceptual debate. Some have argued that integration into global markets deprived multi-class coalitions of the means to support themselves via the statist, inward-oriented economic policies characteristic of classic populists. Moreover, while many have suggested that a strain of populism termed "neopopulism" appeared to thrive in the context of "neoliberal" market reforms (Roberts 1995; Weyland 1996, 2001, 2003; Knight 1998), others, notably Ruth Berins Collier (2001), contend that because neopopulists based their support on the politically demobilized, unorganized informal sector, they differed too greatly from classic populists to merit the label. ${ }^{1}$ Neopopulists were merely "crude imitations of the original, capable of recreating its rhetoric and rituals but unable to reproduce its substance" (Schamis 2006: 32). In fact, Schamis concluded, "Populism as a political actor is history-we should perhaps drop the concept altogether."

I argue, by contrast, that reports of populism's death were premature. The Kirchner coalition, while maintaining export-oriented economic policies, possessed many attributes characteristic of classic populism. A politically mobilized labor movement was a key component of Kirchner's populist coalition, along with domestic industry and unemployed workers' organizations. Sebastián Etchemendy and Ruth Berins Collier (2007), for example, note how unions backed the Kirchner government in exchange for favorable wage agreements. For another, Kirchner's policies to support real wages - sectoral agreements to control domestic prices for consumer goods and subsidies to compensate producers for the costs entailedresemble the broad-based benefits characteristic of classic populism in Latin America because the benefits extended to a wide spectrum of urban workers (Collier 2001). Therefore, populism, even that which involves the incorporation of organized labor into an urban, cross-class alliance, can exist in the contemporary period of globally integrated markets. Indeed, it can thrive by exploiting international markets. $^{2}$

Regarding the political effects of resource wealth, there is a strong intellectual tradition of analyzing the impact of commodity exports on the political and economic history of Latin America. Reliance on the export of agricultural and mineral commodities has been linked to the formation of weak states (Karl 1997; Centeno 2002) and to economic underdevelopment (Cardoso and Faletto 1979). Export elites, particularly agricultural exporters, have traditionally wielded great political power (Smith 1969; Williams 1994; Bates 1997; Paige 1997), and in many

\footnotetext{
${ }^{1}$ The term "neopopulist" was applied particularly to leaders such as Fujimori (Peru), Collor (Brazil), and Menem (Argentina).

${ }^{2}$ By "populism," I follow the more classical Latin-American conceptualization of populism-a predominantly urban, cross-class political coalition that includes, but is not limited to organized labor. Populist policies, then, are those advanced to benefit and to sustain the unity of the heterogeneous groups and actors within the populist coalition; under this conceptualization of populism, they do not define a leader or ruling coalition as populist, but rather follow from it. Universal subsidies, as in classic Latin American populism and in Kirchner's export-oriented populism, are one set of policies consistent with supporting a populist coalition, but in principle there may be others. Moreover, broad-based benefits without a multi-class populist coalition would not necessarily entail populism, just as a rhetorical appeal to the masses is alone insufficient.
} 
places, landowners autonomously controlled the vast countryside (Nunes Leal 1977; Mazzuca 2003).

More recently, a body of research has noted that although resource endowments are associated with open conflict or civil war in many cases (Collier and Hoeffler 1998); in others, resource wealth is linked with political stability (Smith 2004; Snyder and Bhavnani 2005; Snyder 2006). One mechanism linking resources with stability, advanced by Thad Dunning (2008), suggests that in the context of an export boom, windfall profits accruing to the state can provide for a Pareto-optimal, positive-sum distribution of the wealth, relieving political pressures for zero-sum redistributive conflict and its potentially destabilizing consequences. Whether resources are a blessing or curse for political stability is conditional on several factors, such as economic structural and institutional factors that shape the ability of the state, rather than private actors, to appropriate the resource wealth (Snyder and Bhavnani 2005; Snyder 2006), as well as economic inequality and the size of the non-resource sectors of the economy (Dunning 2008).

I extend this line of inquiry into agricultural commodities, which, despite their historical importance in Latin America and their recent resurgence, are largely neglected in the resource-curse literature, which focuses on oil and mineral wealth. ${ }^{3}$ Additionally, I find that the effect of export booms on political stability is further conditioned by the nature of economic linkages between the export sector and the domestic economy (see Hirschman 1977). ${ }^{4}$ When Argentina relied on wage-goods exports, increases in international commodity prices automatically redistributed income to rural producers away from urban workers, thereby heightening political conflict. In contrast, because contemporary Argentina's leading export is not a wage good, high international prices do not have a direct adverse effect on urban real wages, thereby facilitating the types of Pareto-optimal distributive bargains attributed to resource windfalls elsewhere.

Finally, in examining the economic and fiscal linkages between export agriculture and populist political coalitions, this article highlights the importance of understudied causal factors. Aside from a general acceptance that in Venezuela President Hugo Chávez has used oil to fund his political projects (e.g., Shifter 2006), the role of export revenue in sustaining populism and leftism in Latin America has received little attention. Explaining the renaissance of populism in Argentina requires going beyond the political and economic variables customarily associated with populism. Focusing on the role of organized labor is insufficient. Like Edward L. Gibson (1997), I find that commonly overlooked factors outside of the urban centers are essential to understanding the functioning of populist coalitions in Argentina. Instead of focusing on the "peripheral subcoalition" and its ability to supply rural votes to the broader populist alliance, I examine how the rural sector provides fiscal

\footnotetext{
${ }^{3}$ One exception is Isham et al. (2005).

${ }^{4}$ Similarly, the nature of political cleavages, whether along class or rural-urban lines, cannot be attributed solely to relative factor endowments of land, labor, and capital (Rogowski 1987, 1989), but rather is conditioned by these economic linkages. Historically, Argentine political coalitions and their cleavages shifted without changes in factor endowments, depending instead on more a complex relationship between export and domestic sectors.
} 
resources, via export taxes, for purchasing urban mass support. Without these funds to subsidize working-class consumption, and thus real wages, the Kirchner government would have found it much more difficult to maintain the loyalty of organized labor.

Moreover, the rise of export-oriented populism cannot be attributed solely to neoliberalism and the short- or medium-term effects of market reform. The process of market reforms doubtlessly redefined many of the parameters of political competition, including the party system (Roberts forthcoming). In addition, since implementing reforms involved presidents ruling by decree rather than operating through normal democratic institutions and procedures (O’Donnell 1994), market reforms brought significant consequences for how politics is conducted in Argentina (Levitsky and Murillo 2005). Nevertheless, a focus on neoliberalism alone is incomplete. Focusing on the more immediate causes and effects of the market reform process may obscure the "big, slow-moving, and invisible" macro-level causes that are fundamentally important (Pierson 2003).

This article proceeds as follows: first, I outline the logic of the wage-goods cycle, as analyzed by O'Donnell (1978), to explain postwar Argentine politics. Then I discuss the modernization of agriculture, as well as how it has undermined the dynamic of the wage-goods cycle. Following that, I address the question of how the end of the wage-goods cycle has shaped the economic policies of a populist coalition under Kirchner and then provide a discussion of alternative explanations for Kirchner's political and economic Finally, I explore the possible implications of the new populism for political stability in Argentina - with particular attention to the intense conflict over grain export taxes in 2008.

\section{The Wage-Goods Cycle}

Social scientists studying the Argentine economy have long noted the significant effect of commodity prices, particularly of beef, on macroeconomic conditions (e.g., Díaz Alejandro 1970; De Pablo 1975). Beef and wheat were the primary goods consumed by the urban working class, which during the 1960 s spent around $15 \%$ of its income on beef alone (De Pablo 1975: 76). Hence, beef and wheat were "wage goods." At the same time, these two commodities were also Argentina's main exports, together comprising 25 to $50 \%$ of Argentina's export revenue (Díaz Alejandro 1970: 480; see also FAO). As a result, favorable international commodity prices encouraged export booms, but because of "inflación vacuna," or "beef inflation" (De Pablo 1975: 75), domestic prices rose as well, threatening the urban economy. Attempts to mitigate that impact through export restrictions led to balanceof-payments crises due to the trade deficits they provoked. Yet solving trade deficits meant encouraging exports. These counteracting pressures resulted in a "stop-go" pattern of economic growth, with periods of rapid expansion punctuated by foreign exchange crises and severe recessions.

O'Donnell (1978) analyzes the political side of stop-go economics, explaining the cyclical, unstable nature of Argentine politics in the postwar period. Inflation caused by rising beef and wheat prices had the direct effect of reducing the real wages of urban workers: by making the goods they consume more expensive, they were 
effectively made poorer. ${ }^{5}$ I refer to this link between commodity prices and real wages as the "wage-goods effect." Changes in international prices could trigger this effect, but so too could policies that increase or decrease the share of rural production that was exported. Increasing exports reduced domestic supply, thereby increasing domestic prices and reducing real wages. Likewise, restricting exports increased real wages by increasing the supply of beef and wheat to the domestic market, thus lowering prices for urban consumers.

The wage-goods effect, in the context of a strong, mobilized working class, engendered a cyclical pattern of political coalition formation and economic crisis. Fig. 1. stylizes the wage-goods cycle, as discussed by O'Donnell (1978). ${ }^{6}$ The cycle involved (1) shifting political alliances; (2) each alliance's preferred economic policies, especially related to export restriction or promotion; and (3) the ensuing economic crisis that led to the new political alliance. O'Donnell focuses on four actors: the popular sector, made up of the working class and organized middle-class workers, and three fractions of the capitalist class - the rural "pampean" bourgeoisie, responsible for agricultural commodity production; the "large" internationalized urban bourgeoisie, comprised of the largest, most capital-intensive industrial firms, including multinational subsidiaries; and the "local" or "weak" national urban bourgeoisie, encompassing the smaller, less efficient domestic firms. The large bourgeoisie, due to their links with international capital, could survive more easily adverse economic conditions, while the national bourgeoisie needed economic protection to be competitive. Throughout this period, the CGT (Confederación General del Trabajo) was the leading national organization of the popular sector, and the CGE (Confederación General Económica) corresponded to the national bourgeoisie. The rural bourgeoisie was largely represented by the Sociedad Rural Argentina (SRA), while the Unión Industrial Argentina (UIA) was the leading organization of the internationalized fraction of capital. ${ }^{7}$

As Fig. 1. illustrates, political power oscillated between two alliances: a populist one, based on a primarily urban-rural cleavage, and a capitalist one between the dominant groups in the rural and urban sectors, along on a largely class-based cleavage. The populist alliance restricted exports to transfer resources to its support bases. Lowering food prices increased real wages while leaving nominal wages unchanged, benefiting not only the working class, but also national bourgeoisie, which enjoyed both less pressure for wage increases and increased domestic demand

\footnotetext{
${ }^{5}$ Real wages are the wages received by workers (their "nominal" wages) adjusted for inflation. As such, real wages fall if nominal wages do not increase as fast as the inflation rate.

6 The present discussion largely follows O'Donnell's language and remains at a more conceptual, abstract level. For an analysis of the main political organizations and their specific actions in Argentina's unstable postwar political environment, see, for example, Smith (1989) and Collier and Collier (1991), in addition to O'Donnell's work.

${ }^{7}$ It is noteworthy that despite obvious similarities to standard class analysis, O'Donnell's conceptualization of political actors is based on a much more nuanced, contextualized understanding of the relevant groups and interests in Argentine politics. These group actors do not have interests imputed to them by their relations to the means of production; on the contrary, they are grouped more by common political and economic interests, which sometimes cross traditional class lines. See Collier and Norden (1992: 239) for further discussion of this point. For further clarification of O'Donnell's use of terms, see footnote 4 in both the 1978 article and in the original, Spanish-language version (O'Donnell 1977).
} 


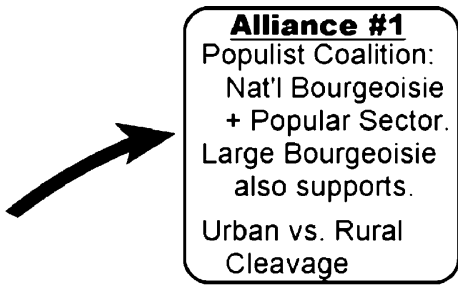

\section{Crisis}

Stagflation.

Recession + Inflation

\section{1}

\section{Economic Policies}

- Devaluation:

Increases exports

- Stabilization program:

Spending cuts,

Anti-statism

\section{Crisis}

Balance of Payments. Imports > Exports

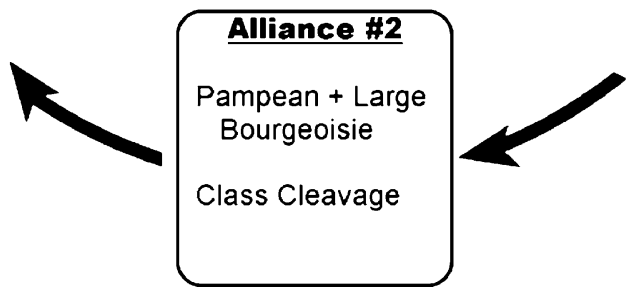

Fig. 1 Wage goods and political cycles

for their goods. In addition, having purchased the support of the working class, domestic capitalists could also push for industrial subsidies as part of an importsubstitution industrialization program. The large urban bourgeoisie went along with these policies, for, as O'Donnell (1978: 13) notes, they were well positioned to benefit from any industrial promotion program by virtue of their size and competitiveness. The rural sector bore the cost of these economic policies, receiving lower prices for their goods.

Ultimately, the restriction of exports led to a balance-of-payments crisis. Faced with this possibility, the large urban fraction of urban capital, fearing the loss of access to international finance markets, withdrew support for the populist government. The most obvious solution to this threat of a balance-of-payment crisis was an increase of exports - which was always in the interests of the rural producers. Consequently, the dominant urban capitalists formed an alliance with the rural sector.

Because of the wage-goods effect, resolving the balance-of-payments crisis through export promotion also had severe consequences. The reduced supply of beef and wheat to the domestic market made real incomes fall and prices rise, resulting in 
"stagflation." Discontent brewed particularly among the popular sector, which experienced the falling real wages most acutely, given the relatively higher fraction of their income spent on beef and wheat products. They revitalized the populist alliance, assuming a defensive posture against the economic losses incurred by export orientation, and demanded policies to revive the domestic economy. Sensing the ability to profit from the situation, the large urban bourgeoisie "looked to their short-term economic interests, supported the economic reactivation policies, and thus rode the crest of the wave of economic recovery" (O'Donnell 1978: 13). They switched their support in favor of the position of Alliance 1, and the cycle restarted. ${ }^{8}$

In addition to the wage-goods effect, two other forces were particularly salient in reinforcing the cycle. First was the strength of organized labor in Argentina to demand wage increases. Their size and mobilizational ability, particularly strong in comparison with labor movements in the rest of Latin America (Collier and Collier 1991: 94-9), made them a useful coalition partner for the national bourgeoisie. Once in power, their size and strength allowed them to push for broad, real wage increases, transferring significant resources from other sectors to the working class, yet exacerbating balance-of-payments problems.

Second, stagnant agricultural productivity entailed that the allocation of rural production was essentially zero-sum: increasing exports to resolve a balance-ofpayments crisis meant decreasing the supply to the domestic market. Productivity increases would have provided a positive-sum solution, increasing exports without affecting domestic supply; however, as O’Donnell (1978: 9) theorizes, uncertainty of future returns inhibited the capital investments needed to increase productivity, leading rural producers to pursue short-run interests over long-run strategies. While some of this price uncertainty is inherent to international commodity markets, much of it in this case derived from Argentina's political instability. In particular, the wage-goods effect ensured that a period of favorable prices for the rural sector would be short-lived, for it encouraged the reformation of the populist alliance against the pro-rural regime. ${ }^{9}$

In sum, O'Donnell (1978) illustrates how structural factors led to cyclical, volatile politics in Argentina. In particular, the fact that Argentina's main export commodities were also the primary components of the urban working-class diet directly linked trade policy and wage policy, and emphasized conflict between the

\footnotetext{
${ }^{8}$ In many cases, economic policy shifted without the populist alliance officially gaining power. Between Perón's governments (1955-1973), the populist alliance never formally entered government: it was a defensive alliance that formed and pushed for its preferred policies, but it did so without holding office. This was one of the rules of the "impossible game": Peronism was banned as a political party (O'Donnell 1973). The populist alliance was, however, repeatedly successful in influencing macroeconomic policy by other means, particularly when economic recession and falling real wages encouraged organized labor and domestic business groups to unite in common interest.

${ }^{9}$ It is noteworthy that debate exists on the subject of rural stagnation in Argentina. Barsky (1991), for example, observes that, following a decade of poor performance, agricultural production began recovering in the $1950 \mathrm{~s}$, slowly increasing in the ensuing decades. The public-sector agricultural research institute, INTA (Instituto Nacional de Tecnología Agropecuaria), was established in 1956, and private-sector efforts also gained impetus around then, though their impact would not be perceived immediately. Still, increases in output were small relative to international trends, slow to materialize, and insufficient to meet the rising demands both for export revenue and for domestic consumption. See also Mallon and Sourrouille (1975: 38-40) and O’Donnell (1978: fn. 28).
} 
rural and urban sectors. These structural factors promoted the formation and reformation of a populist, cross-class coalition and of a capitalist, modernizing coalition. These conditions similarly ensured that each coalition would be unstable, implementing economic policies that would cause its dissolution in an economic crisis. $^{10}$

Additionally, while O’Donnell (1978) emphasizes how Argentine politics could cycle endogenously due to the wage-goods effect, this effect also operated through exogenous shocks that affected the supply or price of beef and wheat. For example, the drought of 1951-1952 drastically reduced the export of agricultural commodities, provoking the balance-of-payments crisis to which Perón's economic policies had been gradually building. In addition, a sharp increase in the international price of beef in 1969-1970 destabilized the authoritarian regime by fueling working class unrest. $^{11}$ These exogenous shifts in the beef and wheat markets reinforced the tendencies of the endogenous cycle and its political effects.

\section{The Rise of Soybean Exports}

In the years that followed, the key structural foundation for the wage-goods cyclethe reliance on beef and wheat as export commodities-changed dramatically. Soybeans, which the Argentine working class does not consume, have rapidly spread across the Argentine countryside in recent decades. Soybean exports, previously nonexistent, now far outpace wage-goods exports.

Argentina's switch to soybeans is part of a global expansion of soybean markets. As income in developing countries rose in the past few decades, global food consumption increased, and soybean products have met much of this rising demand. Soybean meal is a staple in the diet of chicken and pigs raised for meat, and soybean oil has become a key ingredient in many processed foods. More recently, interest has surged in the prospect of using soybean oil as an alternative fuel source. Argentine agriculture has been incorporated into global industrial production chains, feeding Chinese pigs and German biodiesel refineries. As a result, a long-term trend of rising global demand, not transitory price spikes, has fueled this agricultural transformation.

Since the 1970s, wage goods dramatically declined in importance as export commodities for Argentina. As Fig. 2. shows, the share of Argentina's total exports comprised of beef and wheat products has fallen steadily. Soybeans, which were not widely cultivated in Argentina before the late 1970s, replaced these wage goods in the country's export profile. In recent years, the export of unprocessed soybeans and of soybean oil and meal, the two products of the initial seed crushing process, have generated more than $20 \%$ of Argentina's export revenue, tripling the joint share of beef and wheat.

\footnotetext{
${ }^{10}$ This is a highly stylized depiction of the direction of the forces of macropolitical and economic factors on coalition formation and crisis; not all events fit neatly on the cycle. Nevertheless, deviations from this logic were difficult and ultimately unable to overcome the forces of the cycle.

${ }^{11}$ This episode is discussed further in the section about complementary explanatory factors.
} 


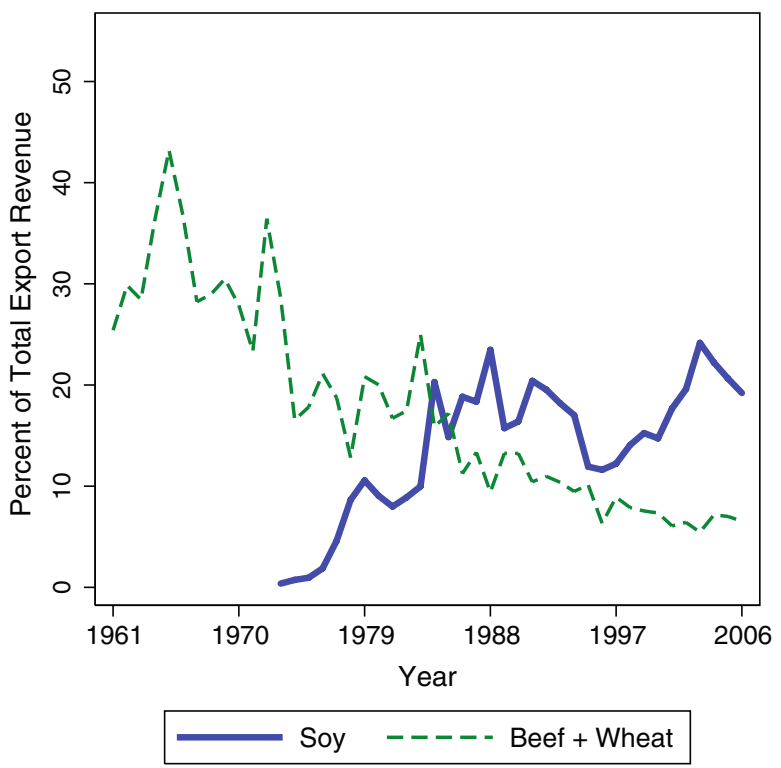

Fig. 2 Declining relevance of wage goods exports in Argentina. Source: FAO and INDEC

Unlike the previously hegemonic export commodities, soybeans have virtually no domestic market. From 1989 to 2006, 94\% of the soybean oil and 99\% of the soy meal produced in Argentina were exported. ${ }^{12}$ By contrast, less than $15 \%$ of Argentine beef was exported between 1990 and $2005,{ }^{13}$ down from $25 \%$ between 1965 and $1976 .{ }^{14}$ Unlike beef and wheat, increases in soy exports have no direct effect on the real wages of the working class.

In principle, the rise of soy cultivation could have indirect, medium- to long-run effects on real wages. As producers shift their land use to soybeans over the years, beef and wheat production might be expected to fall as a result. However, two factors have mitigated this potential indirect wage-goods effect. First, for agronomical reasons, wheat and soy are complementary; indeed, both can be grown in the same year, with wheat in the winter and soy in the summer. In fact, the enhanced profitability of having two harvests a year with the wheat-soy combination was one of the main economic reasons for the initial adoption of soy cultivation in Argentina (Obschatko 1988: 124-5). Therefore, the rise of soy does not threaten to reduce Argentine wheat production.

Second, technological improvements have permitted impressive increases in the production of all agricultural goods. Advances in agricultural machinery, farming

\footnotetext{
${ }^{12}$ Author's calculations based on official government data assembled by the Cámara de la Industria Aceitera de la República Argentina (CIARA), http://www.ciaracec.com.ar/estadistica/.

${ }^{13}$ Indicadores Vacunos Anuales, Secretaría de Agricultura, Ganadería, Pesca y Alimentos, http://www. sagpya.mecon.gov.ar/new/0-0/programas/dma/ganaderia/ganaderia.php, accessed 16 Oct. 2007.

${ }^{14}$ Author's calculations based on official data from INDEC, SAGPyA, and ONCCA, compiled by the Instituto de Promoción de la Carne Vacuna Argentina (IPCVA), http://www.ipcva.com.ar/estadisticas/. In addition, data from the Asociación Argentina Pro Trigo suggest that roughly $60 \%$ of wheat was exported in recent years, though comparable historical figures are not available.
} 
techniques, seed technology, fertilizers, and pesticides in recent decades have increased crop yields, even increasing the carrying capacity of pastures for cattle ranching. ${ }^{15}$ Many of these advances - particularly, no-till (siembra directa) farming with genetically modified "Roundup Ready" seeds and ample application of herbicide-have also allowed the expansion of the agricultural frontier since the mid-1990s into previously marginal lands. Finally, changes in cattle ranching practices have further increased the productivity of land for beef production; these changes include the use of corn and other feed during the winter-instead of sending the cattle to lush winter pastures, freeing that land for agricultural use - and even the recent emergence of "feedlots" similar to those used for cattle raising in the United States. More animals can be raised on less land.

As a result, the production of both soybeans and wage goods does not entail a zero-sum trade-off. Despite the fact that since 1996, more than 5 million hectares of pasture have been switched to agricultural use (Bisang 2007: 190), the number of cattle in Argentina actually increased, due to productivity increases. Beef production reached historic levels, rising nearly 30\% between 2001 and $2007 .{ }^{16}$ Wheat output has also maintained historically high levels since 1996, and has been roughly $50 \%$ greater than in the prior decade (Bisang 2007: 247). This suggests that the rise of soy has not had meaningful indirect effects on the quantity of beef and wheat supplied to the domestic market.

Accordingly, the main hypothesized structural cause of the cyclical, unstable nature of Argentine politics in the postwar period no longer exists. The rise of soy exports in Argentina means that maintaining a stable trade balance and increasing or maintaining real wages are no longer mutually exclusive policy goals. Soy exports can be promoted without affecting the domestic supply of wage goods because the working class does not consume them. Resolving balance-of-payments crises now has less of a direct positive effect on wage-goods prices, and thereby less of a negative effect on real wages. Conversely, now that beef and wheat are less relevant as sources of foreign exchange, their export can be selectively restricted or discouraged, thereby increasing real wages, without provoking a balance-ofpayments crisis, provided that other exports continue.

\section{The Kirchner Coalition}

Under Kirchner, these changes in rural production facilitated the formation of a coalition of urban workers and key fractions of domestic industry. Kirchner cultivated the support of the CGT labor confederation, led by Hugo Moyano, as well many of the larger organizations of unemployed or informal-sector workersthe piqueteros. In addition, Kirchner maintained the backing of leading domestic

\footnotetext{
${ }^{15}$ For one example of this latter usage, see Angel Palermo, "Moderna y eficiente, resurge La Esmeralda," La Nación, 23 Jan. 1999. Henceforth, all citations for news articles will be footnoted, and all are from $L a$ Nación unless otherwise indicated.

${ }^{16}$ Author's calculation based on IPCVA data.
} 
business associations, such as the UIA. ${ }^{17}$ This multi-class alliance between business and labor was similar to the historic populist coalition.

Nevertheless, the new populist coalition was based on an entirely different set of economic policies. Whereas previously, the populist alliance combined an overvalued exchange rate with industrial subsidies, the Kirchner alliance relied on an undervalued exchange rate with wage-goods subsidies. Commodity exporting, rather than the restriction of exports, was central to the new populist coalition's sustainability. For this reason, the rise of soybean production in Argentina allows a populist government to provide broad-based benefits to its supporters while maintaining linkages to the global economy.

The discussion below focuses on two of the main interlocking economic policies that sustained export-oriented populism: currency undervaluation and export taxes. Undervaluation increased the income received from exports, and the taxes appropriated that surplus income for the government. Some of this tax revenue was spent on subsidizing wage goods, thereby controlling inflation-particularly for the working class. This export-oriented strategy became feasible because of the shift away from wage-goods exports. These policies were instrumental in the increase in real wages under the Kirchner government, and they were financed largely by modern export agriculture.

\section{Currency Undervaluation}

Under the Kirchner government, the Argentine central bank heavily intervened in the foreign exchange market, preventing the peso from appreciating in value. Fig. 3 plots the exchange rate in Argentina since 2003, in pesos per US dollar, along with the exchange rate for the Brazilian real. For about a year and a half after Kirchner took office in May 2003, the peso and the real were roughly equivalent. Since then, the two currencies have diverged, with the real-along with the main global currencies - gaining in value relative to the dollar, while the peso slowly but steadily lost value against the dollar. ${ }^{18}$

The Brazilian real appreciated for several reasons, including the influx of dollars from booming commodity exports - particularly soybeans - as well as from record levels of foreign investment and the general decline of the dollar around the globe. One would expect that the similar economic conditions in Argentina-soaring agricultural exports and a falling dollar-would also result in a stronger peso. This did not occur, largely because of the Argentine central bank's activity in the foreign exchange market. Fig. 4. shows the intervention of the central bank in the currency market during this period. During Kirchner's term in office, the central bank purchased nearly US\$45 billion from foreign exchange receipts. ${ }^{19}$ By selling pesos

\footnotetext{
${ }^{17}$ For further discussion of the various organizations' relationships with the Kirchner government, see, for example, Svampa and Pereyra (2005: 356-60) and Etchemendy and Garay (forthcoming).

18 The effect is not specific to the dollar. The Argentine central bank's multilateral exchange rate index, calculated as an average of world currencies weighted by their importance as trading partners, also gradually increased throughout this period. See "Indice de Tipo de Cambio Real Multilateral," www.bcra. gov.ar.

19 Author's calculation from statistics collected by the Banco Central de la República Argentina (BCRA), www.bcra.gov.ar/pdfs/polmon/seriese.xls, accessed 16 Jan. 2008.
} 
Fig. 3 Exchange Rates in Argentina and Brazil, 2003-2007. Source: IMF

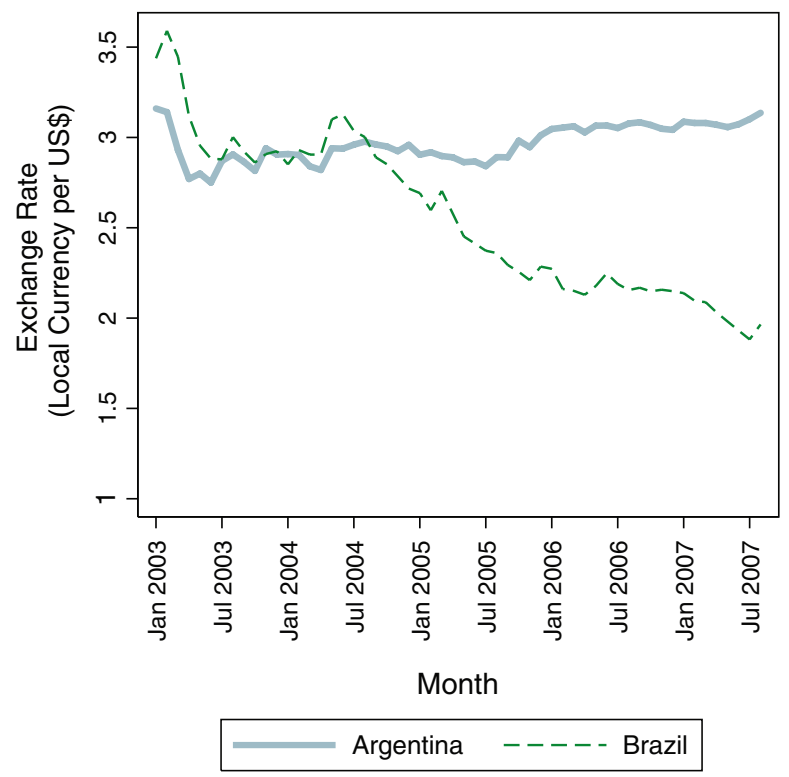

(or peso-denominated bonds) to buy dollars, the central bank depressed the value of the peso below what it otherwise would have been.

Undervaluation served several functions in Kirchner's export-oriented populism. First, maintaining a positive trade surplus and increasing central bank reserves shored up Argentina's monetary position after the 2001-2002 crisis. After a decade of mounting sovereign debt and dwindling central bank reserves due to the pesodollar peg (Convertibility), this policy eliminated the need to borrow to sustain an

Fig. 4 Argentine central bank interventions in currency markets under Kirchner. Note: 21 day moving average of daily transactions. Source: BCRA

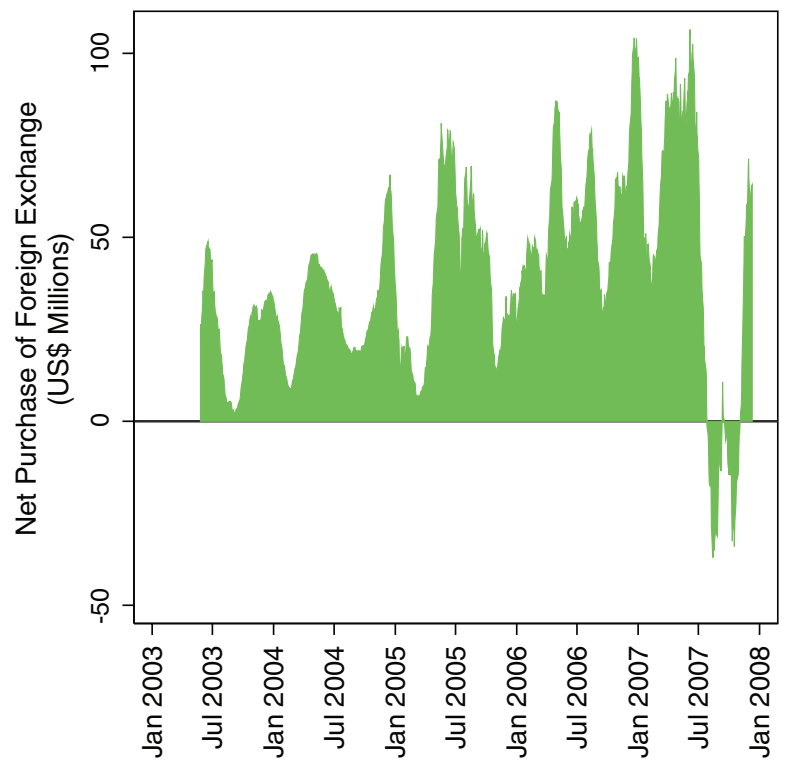


exchange rate, ultimately increasing Kirchner's independence from international lenders. Second, by eschewing the currency peg and the creeping appreciation and overvaluation of the peso it caused - a source of widespread frustration by the end of the 1990s-Kirchner's active pursuit of depreciation was a generally popular policy. Third, undervaluation effectively subsidized domestic industry by increasing the price of rival imports and, in a post-ISI open economic model, by making their exports more internationally competitive. This helped to maintain part of Kirchner's support coalition. ${ }^{20}$ Fourth, since undervaluation promotes all exports, it fueled a boom in agricultural commodity exports, which have long been one of Argentina's natural comparative advantages. This resulted in a massive influx of wealth, which the government sought to appropriate.

\section{Export Taxes and Their Uses}

Historically, export taxes have served two main purposes in Argentina. Before the Great Depression, export taxes were the main source of fiscal revenue for the government, generating over half of total tax revenue between 1900 and 1930, though this share gradually declined (Díaz Alejandro 1970: 490). As urbanization and industrialization proceeded and domestic demand for agricultural goods as food for urban workers increased, export taxes acquired a second use: insulating the domestic market from changes in the external sector. By driving a wedge between domestic and international prices, export taxes mitigate the inflationary pressure caused by rising export prices, whether resulting from currency devaluation or from exogenously determined increases in international commodity prices. Both of these uses are particularly salient in the context of an economic crisis, in which both an immediate fiscal stimulus and control over the side effects of devaluation may be desirable.

The interim Duhalde government's use of export taxes in response to the financial crisis of 2001-2002 exploited both functions. Export taxes, which had been effectively eliminated under Carlos Menem (1989-1999), were reinstated March 4, 2002. Resolution 11/2002 of the Ministry of Economy and Infrastructure established export taxes of $10 \%$ on raw material exports and $5 \%$ on processed agricultural goods (e.g., soy meal and oil), industrial goods, and energy. As the peso continued to devalue, the export taxes were increased the next month to $20 \%$ on all oilseeds and their derivatives. A 3.5\% additional tax on unprocessed oilseeds, as well as similar levies on raw leather - the only export taxes to survive the Menem administrationalso remained. The fiscal boom that this generated was critical to the cash-strapped government recovering from the economic crisis. Export tax revenue was initially linked to unemployment assistance, instrumental in defusing the crisis. ${ }^{21}$

A closer examination of the recent use of export taxes, and particularly of their intensification under Kirchner, suggests key differences with historical periods.

\footnotetext{
${ }^{20}$ The leadership of business associations such as the UIA on many occasions expressed "unrestricted support" for Kirchner's economic policies. See, e.g., Alejandro Rebossio, "Pagani elogió a Kirchner, pero pidió medidas," 23 May 2004, and "Para la UIA, ya se pagan salarios muy dignos," 24 Apr. 2005.

21 “Con las retenciones se otorgarán subsidios a más de 2 millones de desocupados," 4 Mar. 2002.
} 
While export taxes may shield the domestic market from the effects of the undervalued peso and high international prices for some commodities, such as wheat, they do not perform this function for all agricultural goods. Because soybeans have no domestic market, taxes on their export can only serve to increase government revenue. To be sure, soy played a large role in funding Kirchner's government. Export taxes comprised 8 to $11 \%$ of the Kirchner government's total tax receipts, ${ }^{22}$ and around two-thirds of this-nearly US\$2 billion in 2006-came from soy exports. ${ }^{23}$

Increasingly, Kirchner exploited soy as a source of tax revenue, among other things, to cancel the wage-goods effect of increased exports. In January 2007, Kirchner increased export taxes on soy products to $24 \%$ on oil and meal and $27.5 \%$ on the export of the unprocessed oilseed. This additional soy-specific tax of $4 \%$ was forecast to generate an additional US\$400 million in fiscal revenue in $2007 .{ }^{24}$ The stated use of the new funds was the subsidy of food production for domestic consumption, including beef, dairy, chicken, and wheat flour, administered by ONCCA, the state's Oficina Nacional de Control Comercial Agropecuario. Through early October $2007,30 \%$ of the funds released by ONCCA had gone to the poultry industry (Arg\$116 million), 30\% to dairy, and 15\% (Arg\$59 million) to wheat. ${ }^{25}$

With fiscal resources available for targeted subsidies, the government was better able to broker and support price agreements with businesses, thereby controlling inflation. In some cases, the subsidies were intended to compensate producers for the difference between international prices and the lower, officially set domestic price. For example, both wheat farmers and flour mills received subsidies. Producers selling to the mills for the domestic market received the official price from the mills; they then had to submit paperwork to the federal government to receive the subsidy. The mills did the same when they sold their flour. The purpose of this program was not to increase total production but rather to increase the share of production destined for the domestic market - at prices below those in the international market.

In the case of beef, some subsidies sought to lower domestic prices by increasing supply. The government directed a share of the soy export tax revenue (Arg\$10.7 million, through early October 2007) to subsidizing cattle feedlots, which can rapidly fatten animals to slaughtering weight. Since the end of February 2007, feedlot owners benefited from subsidies on corn, the principal animal feed used in this type of production. This compensation was designed to minimize the impact of high international corn prices. The goal was to promote the continuing expansion of feedlots, which in only a decade rose to produce $40 \%$ of the beef supplied to the domestic market. $^{26}$

\footnotetext{
${ }^{22}$ Author's calculation from official government statistics (Ministerio de Economía y Producción, Secretaría de Hacienda, Subsecretaría de Ingresos Públicos; http://www.mecon.gov.ar/sip/basehome/ pormes.htm). Export taxes, minus the refund of the value-added tax paid on inputs in the export production (reintegros), as a percentage of total tax receipts.

${ }^{23}$ Fernando Bertello, "Suben las retenciones a la soja para frenar los precios," 12 Jan. 2007.

${ }^{24}$ Fernando Bertello, "Suben las retenciones a la soja para frenar los precios," 12 Jan. 2007.

${ }^{25}$ Sociedad Rural Argentina, Instituto de Estudios Económicos, "Resultados de las compensaciones otorgadas al Sector Agroalimentario," http://www.sra.org.ar/, accessed 16 Oct. 2007.

26 José Crettaz, “Crecería la oferta de carne de corral,” 27 Feb. 2007.
} 
These subsidies served to complement the government's other policies designed to control the prices of wage goods. In addition to the export taxes themselves, Kirchner sought to reduce domestic prices by restricting or completely blocking exports of wage goods. In one key episode, the Kirchner government announced in March 2006 a 180-day embargo on beef exports to increase the supply of beef to the domestic market. Consequently, beef prices at the Liniers Market in Buenos Aires fell $15-31 \%$ over the next few months, eliminating the price gains of the past year. ${ }^{27}$ Not surprisingly, this move provoked a sharp reaction from cattle ranchers, but given the small share of export revenue generated by beef, the government was not pressured by the prospect of a trade imbalance. Even so, as prices fell, the export ban was gradually relaxed over the ensuing months (Azcuy Ameghino 2007: 278-88), though export controls remained in place for the remainder of Kirchner's term. Yet, facing steadily rising international beef prices, export restrictions alone became insufficient to control domestic prices and ensure supply, leading the government to turn to the subsidy program based on soy-specific export taxes.

Beyond wage-goods subsidies, revenue from export taxes helped to sustain a broad increase in government spending under Kirchner, much of which was allocated by presidential decree. ${ }^{28}$ In addition to food, Kirchner subsidized other important wage goods, particularly energy (electricity, petroleum, and natural gas) and transportation, as well as increased public sector salaries and pensions. Between 2003 and 2006, government spending on energy and fuels increased sevenfold, while transportation expenditures more than tripled (Etchemendy and Garay forthcoming). Energy and transport spending reached Arg $\$ 12.5$ billion (US\$4.1 billion) in 2006, roughly $12 \%$ of the total budget. ${ }^{29}$ These subsidies allowed the government to compensate private-sector energy and transportation firms for the low, officially mandated prices for their goods and services, which for some had remained frozen since the 2002 devaluation.

As the 2007 elections approached, the fiscal expansion accelerated, increasing by $54.3 \%$ in the first 9 months of 2007 alone. ${ }^{30}$ To help fund this campaign-year surge in government spending, Kirchner again raised export taxes on grains and oilseeds after the October 2007 elections. The tax rate on soybeans increased from 27.5 to $35 \%$ on unprocessed soybeans and from 24 to $32 \%$ on oil and meal; rates on other grains also increased between 5 and $10 \%$. This increase was forecasted to bring in an additional US\$1.5 billion to the federal government, raising the projected total export tax revenue from grains alone for the 2008 harvest to US\$7.4 billion. $^{31}$

While rising export taxes did not account for all of the fiscal expansion, they had two clear political advantages to Kirchner over other major taxes, such as the income tax. First, in stark contrast with other taxes, export taxes could be increased without

\footnotetext{
${ }^{27}$ Price changes varied based on the category of animal sold. Author's calculations based on Mercado de Liniers data, compiled by the Instituto de Promoción de la Carne Vacuna Argentina, http://www.ipcva. com.ar/estadistica.php.

${ }^{28}$ Laura Serra, "Kirchner subió el gasto un 12 por ciento por decreto," 25 Aug. 2007

29 Author's calculations based on data from the Asociación Argentina de Presupuesto y Administración Financiera (ASAP).

${ }^{30}$ Rafael Mathus Ruiz, "El aumento del gasto llega al 54,3\%," 12 Nov. 2007

31 José Crettaz, "Fuerte alza de las retenciones para apuntalar la recaudación," 8 Nov. 2007
} 
legislative approval. Article 775 of the Customs Code (Código Aduanero) from 1981 delegates the authority to set export duties from the legislature to the executive. This clause of the customs law, established during the most recent military regime, intended primarily to increase the government's agility in responding to macroeconomic crisis. Nevertheless, it was increasingly exploited in noncrisis times under Kirchner to raise revenue without potentially costly congressional debate. Increasing export taxes by decree constrained the ability of the affected sectors to defend their interests and saved the Kirchner government the expense of buying legislative support for a tax increase.

Second, since export taxes are not factored into the federal revenue sharing agreements (coparticipación), export taxes did not have to be shared with the provinces. Consequently, their imposition coincided with a centralizing shift in the distribution of fiscal resources within the Argentine federal system. Between 2001 and 2006, the share of national tax receipts kept by the federal government (excluding social security) increased by $5.4 \%$, up to $57.8 \%$, while the share transferred to the provinces fell to $23.1 \%$. Export tax revenue accounted for most of this shift. ${ }^{32}$ Because this export tax revenue did not have to be shared, Kirchner had greater discretion over how to spend it. Although revenue from other taxes also rose during this period, increasing export taxes played a critical role in the expansion of federal-level spending programs, including wage-goods subsidies, under Kirchner.

Overall, Kirchner used an undervalued exchange rate coupled with export taxes to support his populist coalition. Undervaluation subsidized domestic industry-one of his support bases - and increased the surplus generated by export agriculture, the taxation of which provided the resources for his other political objectives. Some of the export tax revenue went directly to public sector workers as nominal wage increases; other resources went toward subsidizing consumption goods. These latter resources also bolstered private sector real wages by controlling inflation, which allowed business to provide greater real wage increases with more modest nominal wage increases. This allowed both urban capital and labor to benefit, reinforcing the cohesion of the multi-class populist coalition. ${ }^{33}$

The key to this system was commodity exporting. The shift on the pampas from beef and wheat production to soybean cultivation allowed the establishment of export-oriented populism under the Kirchner government. Historically, in the wage-goods cycle, conditions that favored commodity exporting, including an

\footnotetext{
${ }^{32}$ That is, for the 2006 data, subtracting export tax revenue from both total tax receipts and the national government share and then recomputing the national and provincial shares yields very similar numbers to the 2001 shares, the year before export taxes were imposed. Data in this paragraph again come from Ministerio de Economía y Producción, Secretaría de Hacienda, Subsecretaría de Ingresos Públicos.

${ }^{33}$ Certainly, Kirchner also derived important political support from the other ways in which he spent the expanding resources. For example, spending on public works also increased significantly under Kirchner (Levitsky and Murillo 2008), and the president's discretion over budgetary allocation allowed him to use these funds to reward key supporters with targeted benefits - and to maintain their loyalty with threats of withholding funds. Recipients included loyal governors, as well as leaders of unemployed workers' organizations. Some piqueteros were given posts in the ministries and secretariats responsible for spending public works money (Etchemendy and Garay forthcoming). One such leader, Luis D’Elía, purportedly conditioned his acceptance of a housing secretariat position in government on the size of the budget he would manage. See María Cecilia Tosi, "D'Elía pone condiciones para sumarse al gobierno de Kirchner," 13 Jan. 2006.
} 
undervalued exchange rate and high international prices, were associated with political unrest. Organized labor, which saw its real wages fall due to the rising prices of beef and wheat, mobilized to demand wage increases. Domestic industry also suffered from the resulting stagflation. These groups united to push for economic policies, including general export restrictions, which would benefit their common urban interests.

After the switch to soybeans, agricultural exports can be allowed, even encouraged, without directly endangering the economic standing of the popular sector. Promoting exports and then taxing them may provide even greater resources to sustain populism without generating economic crisis. Similarly, the government can selectively manipulate the market for beef and wheat, even banning their export, without incurring a trade deficit and the risk of a balance-of-payments crisis because it no longer depends on the same commodity to provide both foreign exchange revenue and food for urban workers. As a result, the wage-goods cycle of recurring crises, driven by the price of beef, has been broken, and new political and economic strategies are feasible.

\section{Complementary Explanatory Factors}

Clearly, many factors were involved in leading to the rise of export-oriented populism in Argentina. This discussion has focused on one structural cause- the change in rural production for export - and has attempted to trace through, both logically and empirically, its effect on political coalitions, their economic policies, and their stability. To bolster these claims, I discuss two other factors relevant for the emergence of export-oriented populism - changes in organized labor and favorable international market conditions - to show that these complementary explanations are important yet incomplete. Neither would be sufficient to sustain export-oriented populism in the absence of the shift in agricultural commodity production.

\section{Labor}

One relevant political factor is the evolution of the working class. Etchemendy and Collier (2007) argue that, while organized labor was weaker under Kirchner than it was a half-century ago, it was still large enough to be an important coalition actor. They describe how Kirchner's government cultivated the support of organized labor by endorsing collective bargaining and nominal wage increases. However, due to the rise of a large informal sector, unionized workers comprised less than half of the working class; they describe the situation as "segmented corporatism" to highlight the growing divide between formal and informal labor. The smaller size of the formal sector, by limiting the wage demands made of the government, reduced the inflationary potential of granting nominal wage increases because fewer people received them. Therefore, the government could maintain the support of organized labor with less risk of economic crisis. ${ }^{34}$

\footnotetext{
${ }^{34}$ Recall that, within the O'Donnell (1978) framework, the size and strength of organized labor was one of the key forces preventing an exit from the wage-goods cycle.
} 
Attention to wage goods and changes in Argentina's export profile complement this story. Changes in organized labor alone do not account for the Kirchner government's economic orientation, particularly its pursuit of an undervalued exchange rate. Historically in Argentina, devaluation had the double inflationary effect of raising the price of exports while also increasing the price of domestically produced wage goods that were reoriented to export markets. These inflationary pressures would erode any gains in real terms from the nominal wage increases. Because of the rise of soybean exports, leaders can now promote exports and still sustain a populist coalition.

Furthermore, the system of price controls and wage-goods subsidies allowed the Kirchner government to provide greater real wage increases with limited nominal wage increases. In addition to the clear wage gains to organized labor in the formal sector during the Kirchner government, as Etchemendy and Berins Collier (2007) illustrate, this system also extended moderate wage benefits to the informal sector, which should, at the very least, prevent the social chaos of 2001-2002. These wagegoods subsidies would not have been possible without the taxes on soybean exports. As a result, the changes in agricultural commodity production allowed Kirchner to fund segmented corporatism.

\section{International Markets}

Second, international market conditions also supported the emergence of exportoriented populism under Kirchner. International commodity prices, and soybean prices in particular, soared during Kirchner's government. As China's economy boomed and its citizens became more affluent, consumption of meat increased, so demand for soybeans as animal feed increased. At the same time, the United States accelerated its promotion of a corn-based ethanol industry as an alternative fuel source; farmers there switched in large numbers from soy to corn, thus reducing global supply. Soybean prices steadily increased starting in early 2006, rising around 60\% from September 2006 to September 2007 alone. ${ }^{35}$ Consequently, one could suppose that Kirchner's strategy of taxing windfall agricultural profits to support a populist coalition was made possible by high prices for Argentina's main exports, regardless of how the export commodity is linked with the domestic market. The switch from beef and wheat to soybeans, and the subsequent end of the wage-goods cycle, would be irrelevant.

Comparison with a historical case highlights the importance of the shift in export agriculture away from wage goods. It suggests that if Kirchner's Argentina still relied on beef or wheat exports, booming commodity prices would have triggered the wage-goods effect, thereby undermining the potential gains for populist coalitional stability. During the military regime of 1966-1973, the economic program advanced by Minister of Economy Adalberto Krieger Vasena used similar policies to those employed under Kirchner to stabilize the economy and appropriate rural profits for the government. In March 1967, Krieger announced a comprehensive economic program, intended both to "deepen" industrialization and to promote

\footnotetext{
${ }^{35}$ Prices also surged in the second half of 2003, peaking in early 2004, before falling back. See http:// www.ciaracec.com.ar/estadistica/ for Argentine FOB price data.
} 
macroeconomic stability. Two components are particularly relevant. First, the peso was devalued sharply, from 255 to 350 per US dollar, and export taxes were imposed on raw materials. This "imperfectly compensated devaluation," as it was called, redirected the devaluation's windfall revenues away from rural exporters to the state, which could use the funds for its industrialization project. Second, wages and prices were controlled through sectoral agreements. Krieger reached price agreements with the largest industrial firms, and the rest were expected to follow (Mallon and Sourrouille 1975; Smith 1989).

The combination of these policies, in conjunction with several others, was intended to control inflation and keep the balance of payments balanced while avoiding recession, as well as to redirect the surplus away from both the rural sector and urban workers toward leading industrial sectors. To promote the deepening of industrialization, the program needed to accumulate dollars, both through increasing exports via devaluation and through attracting foreign investment, with which Argentine industry, with state assistance, could purchase heavy capital goods from abroad. While having different ends than those of the Kirchner government, the means adopted by Krieger Vasena, as well as the intermediate goals of stability and growth, were similar in many ways.

In terms of these intermediate goals, Krieger's program was successful, at least in the short run. GDP increased by a cumulative $21.5 \%$ in the $1966-1970$ period. Inflation was tamed, with the cost of living increasing only $7.6 \%$ in 1969 , down from more than 30\% in 1966 (Smith 1989: 76). Control over prices then permitted control over wages as demand for wage increases was muted. ${ }^{36}$ Accordingly, real wages remained relatively stable, falling by $3.8 \%$ during the same period (Smith 1989: 77).

Yet stability was ephemeral. Both political and economic factors, in many ways deriving from the regime's policies, caused a crisis that led to the fall of the military regime's President Juan Carlos Onganía in 1970, and ultimately to the return to civilian rule a few years later. ${ }^{37}$ Certainly, the cordobazo - the mass uprising in the city of Córdoba in 1969, which initiated a period of intense, nationwide workingclass mobilization-was critical in igniting widespread, open resistance to the regime.

However, another factor accelerated the regime's unraveling: a sharp increase in the international price of beef. Beginning in the latter part of 1969, beef prices began to rise, gaining 20\% over the course of the year (Smith 1989: 147). Beef prices further rose 15-27\% from December 1969 to March 1970 (Duejo 1973: 81-2), and they continued their rapid increase throughout 1970, maintaining high levels at least through 1972. As William C. Smith (1989: 150) notes, rural producers, who had been excluded from the regime's state-led development program, exploited the situation and redirected the economic surplus to themselves. The price spike unleashed the wage-goods effect by driving up the consumer price index and slashing the real wages of urban workers (De Pablo 1975: 75-6). This led to intensifying demands for (nominal) wage increases and more strikes, which the

\footnotetext{
${ }^{36}$ One should not overlook the key role played by repression in further muting workers' demands.

${ }^{37}$ For a more comprehensive discussion of the military regime's crisis, see, for example, William C. Smith (1989).
} 
government, its position relative to labor weakened by the cordobazo and its aftermath, felt compelled to grant. Since the regime could no longer guarantee wage controls, firms stopped abiding by price agreements, further fueling both the inflationary spiral and political tensions (Smith 1989: 153).

The disintegration of the military regime's political and economic support-in part caused by the wage-goods effect-suggests the importance of commodity exports and the nature of their linkages with the domestic economy. One key point is that an increase in international commodity prices - which, for most commodityexporting countries, is associated with economic growth and political stability-led to intensified distributive conflict and political chaos. Krieger's economic program, which largely depended on an influx of foreign capital to fund industrialization, could not survive the advent of the favorable international prices that would generate such a surplus.

This situation contrasts sharply with that of the Kirchner administration. Since soybeans surpassed beef as Argentina's leading generator of export revenue, the wage-goods effect has been tamed. Rather than encourage instability, increasing international commodity prices under Kirchner reinforced the government's position. Soaring soybean prices increased the size of the surplus available for the government to tax through export taxes, yet, since there is no domestic market for soy, they had no direct effect on domestic consumer prices. High soybean prices supported the government's program of controlling domestic prices with subsidies to producers of consumer goods. This ability to compensate potential losers from price controls reinforced Kirchner's capacity to reach those price agreements, in sharp contrast with the position of the military regime in the early 1970s, which had lost credibility with business. In sum, while Kirchner definitely benefited from high international commodity prices, because Argentina now exports soybeans instead of beef significantly enhanced his ability to convert an export boom into political stability.

\section{Stabilized Populism or a New Cycle of Instability?}

How does the change in rural production affect the future prospects of populism in Argentina? Combining export orientation with populism, in the context of globalized markets, resolves many of the issues that historically prevented political stability under populism. First, export orientation solves a key weakness of populist politics: it provides resources to maintain support. Traditional populists attempted redistribution and printing more money; the former intensified elite opposition and the latter caused inflation. They also used export restrictions to increase the supply of wage-goods to the domestic market, which stifled Argentina's comparative advantage as an agricultural producer and ultimately provoked balance-of-payments crises.

In the contemporary context of liberalized markets, sustaining a populist coalition is complicated because, as Kurt Weyland (2003: 1095) suggests, international market forces strongly discourage expansionary monetary policy and deficit spending. Even so, privatization allowed Menem, the market-reforming neopopulist of the 1990s, to spend like a populist for several years. However, privatization is an unsustainable 
fiscal source, limited by the availability of state assets to sell. Menem was further pressured, particularly in his second term, by intensifying provincial demands for greater fiscal transfers (Eaton 2004: 151-4).

Kirchner, constrained by international market forces and lacking further state assets to sell, could not rely on old models of funding populism. But export promotion could provide a revenue source for sustaining a populist coalition, especially in the context of globalized markets - provided that the export is not a wage good. Moreover, within the Argentine institutions of fiscal federalism, export promotion has a further benefit for populists because export tax revenue belongs exclusively to the central government, increasing their leverage over the provinces.

Second, export-oriented populism under Kirchner was profitable for all relevant actors. Undervaluation of the currency, by promoting exports, counteracted some of the rural sector's losses caused by export taxes. As long as export taxes did not expropriate all of the profits from agriculture, soy producers would continue to farm. Indeed, many exporters thrived. For example, in August 2007, Los Grobo-one of Argentina's largest soy producers - announced a plan to invest US\$20 million to increase significantly their grain storage capacity. This was one of a series of major expansions that the firm conducted in $2007 .{ }^{38}$

Furthermore, as international prices rose, the government was able to increase export taxes further without jeopardizing the profitability of modern export agriculture. Some in the rural sector have suggested that acquiescence to Kirchner's export tax increases was promoted because rapidly rising commodity prices quickly erased the potential losses incurred by the taxes. ${ }^{39}$ In addition, the expanding pool of fiscal resources enhanced Kirchner's ability to maintain the cohesion of the populist coalition. By subsidizing instead of merely dictating price controls, Kirchner helped to prevent fissures between urban capital and labor, divisions that historically weakened the populist alliance whenever economic growth resumed. In sum, Kirchner's economic policies distributed the economic gains from export promotion and enhanced political stability, at least in the short run.

Conversely, export-oriented populism may generate new sources of instability. Kirchner wove a complex, interlocking set of market interventions to support his coalition, and Cristina Fernández de Kirchner, his wife and presidential successor (2007-present), has pledged continuity. The breakdown of any of these programs could unravel the entire system. Undervaluation, for example, is one key to the alliance: it transfers resources to the export sector and, through the export taxes, to the central government, which uses the funds to subsidize the working class. The greater the undervaluation, within reason, the more the various actors in the alliance benefit. Yet booming soy exports place upward pressure on the peso, for the exports bring dollars into the country. To prevent currency appreciation, the central bank purchases dollars using bonds, which are indexed to inflation. This gave the Kirchners an additional incentive to control inflation beyond supporting real wages.

\footnotetext{
${ }^{38}$ Mercedes Colombres, "Los Grobo amplía su capacidad instalada y lanza una serie de ON," 20 Aug. 2007.

${ }^{39} \mathrm{I}$ base this on interviews conducted in Argentina between February and June 2008. Subsequent references to interview responses also refer to this period.
} 
Such an imperative is partially at the root of the prolonged crisis at Indec, the government census bureau, over a January 2007 retooling of the inflation index. Since then, official inflation numbers were widely believed to be much lower than actual inflation. For example, Indec reported a cumulative inflation rate for 2007 of $8.5 \%$, while conservative independent estimates place the real rate at double that figure. ${ }^{40}$ The apparent motive for this intervention was to decrease the value of inflation-indexed debt: the official inflation statistics do not affect the actual price of bread on the street, but they do affect the value of bonds. The government's savings on debt service and bond payments from the lower official inflation statistics have been estimated to be nontrivial.

Official statistics aside, actual inflation may also strain the populist alliance. By 2008, all sectors, including the coalition's base in industry and organized labor, expressed concern over rising prices. High inflation, indicating that wage-goods subsidies and sectoral agreements are insufficient to control prices, threatens labor's real wage gains. This could lead to conflict within the coalition over key economic policies, such as the undervalued exchange rate, which favors domestic industry yet exacerbates inflationary pressures. $^{41}$ Even, while inflation levels may constrain economic policy, it is unclear how high inflation must become before it threatens the disintegration of the populist alliance from within. In practice, both Kirchner governments, as well as domestic industry and organized labor, have appeared willing to accept the risk of higher inflation in exchange for greater economic growth and lower unemployment. Even so, inflation could compound itself and spiral out of control if left unchecked.

In 2008, a new threat to export-oriented populism emerged: a united rural sector mobilized against the increasing export tax burden they faced. Resolution 125/08 of the Ministry of Economy and Production, announced on March 11, increased export taxes on soy and sunflower again and instituted a scale of progressive taxation, with tax rates increasing as the commodity prices increase. When introduced, this entailed an increase in the rate on soybean exports from 35 to $44.1 \%$. The new system also effectively lowered the export tax rates on wheat and corn, given the day's prices.

Surprising nearly everyone involved, this resolution sparked an intense fourmonth nationwide conflict between the rural sector and the government. Farmers assembled and blocked major roads throughout the country, organizing more highway protests than occurred in 2001 and 2002 during the depths of Argentina's financial crisis. ${ }^{42}$ Both sides organized mass rallies, and the ruralists assembled more than 200,000 protesters on two separate occasions. Ultimately, after the narrow defeat in the Senate of a bill that would have given legislative backing to the executive resolution, the president rescinded the new system of progressive export taxes on July 18, reestablishing the status quo ante of fixed export taxes.

The government surely did not anticipate the intensity of the rural sector's resistance to the new measure. The new tax only partially appropriated the windfall generated by soaring international prices; prices available to the producer (net export taxes) were still

\footnotetext{
40 “La inflación oficial fue del 8,5\% en 2007," 8 Jan. 2008.

${ }^{41}$ Cristina Fernández de Kirchner has suggested that exchange rate policy may need to be revised to control inflation, a statement that troubled the UIA. See "La Presidenta, en contra de un tipo de cambio muy alto," 19 Sep. 2008.

42 "Los cortes ya superan el récord de 2001," 2 Jun 2008.
} 
higher than those at the time when the current crop had been planted several months earlier (Ministerio de Economía y Producción 2008). More important, previous export tax increases had revealed the rural sector's unwillingness or inability to resist the government. Rural political organization at the national level is divided among four separate groups - SRA, Confederaciones Rurales Argentinas (CRA), Federación Agraria Argentina (FAA), and Confederación Intercooperativa Agropecuaria (CONINAGRO). All have historically different membership bases, ranging from large to small producers and, in the case of CONINAGRO, rural cooperatives; and all have diverse - and frequently conflicting - interests as a result. For example, the FAA has advocated a rural tenancy law and other state interventions to protect its base of small farmers, while the SRA, traditionally composed of large landowners, has long opposed such policies. Until 2008, these intrasectoral tensions had inhibited united opposition to the export tax regime. Nevertheless, the four organizations were able to forge a united front and mount a campaign against the government's policies, ultimately succeeding in their immediate goal. ${ }^{43}$

While a full analysis of the 2008 rural conflict would be premature and would exceed the scope of this article, two preliminary conclusions relevant for the present discussion of export-oriented populism may be advanced. First, despite what on one level was a broad rejection of the Kirchners' economic model, the basic system of export taxes and wage-goods subsidies survived intact. Throughout the four-month battle over the progressive export tax system, rural leaders asked for the restoration of fixed $35 \%$ taxes on soy exports - not their complete elimination. The rural leaders appeared to have accepted, albeit begrudgingly, a status quo that includes export taxes, at least conditional on high commodity prices. Despite the political defeat suffered by the government, the redistributive mechanisms of export-oriented populism remained in place.

Second, the rise of soybean cultivation, and particularly its intensification under Kirchner, may have contributed to uniting the rural sector. In part, due to rising international soybean prices, and in part, the result of Kirchner's policies to reduce the price of wage goods - for example, the beef export restrictions - relative prices facing farmers have increasingly favored soy cultivation. Anecdotal evidence suggests that in the central agricultural region, most small and large producers grow at least a little soy: some do so for profit maximization; others, simply because it is profitable enough to compensate for weaker returns on the crops or livestock they have traditionally raised.

\footnotetext{
${ }^{43}$ Interviewees in the rural sector suggested several proximate causes for why the rural sector protested this export tax increase and not before. In addition to standard tipping-point explanations, many highlighted certain aspects of the new system of mobile tax rates. In particular, since the highest marginal tax rate was $95 \%$, farmers had little incentive to hold harvested grain for sale at a later date because they would only receive $5 \%$ of any possible price increase. This had potentially adverse effects on futures markets and agricultural credit mechanisms linked with futures, and promised to depress grain prices further at harvest due to oversupply. Others suggested that the timing of the increase may have affected farmers' perception of its effect. Resolution 125 was introduced right at the time of the harvest, which may have increased the sensation that the government was taking money out of their pockets, even though the price net export taxes in March was still greater than in October. Moreover, the announcement immediately followed the week of the annual Expoagro, a large farm exposition at which many farmers placed orders with tractor firms to purchase new machinery. In a sense, the windfall profit of the coming harvest had in many cases already been spent; so rather than simply sharing the wealth in a positive-sum manner, the export tax increase seemed to create winners and losers.
} 
The profitability of both small- and large-scale agriculture increasingly depends on soybeans. Soy thus provides a common interest among the various fractions of the rural sector, despite their other antagonistic goals. Consequently, a government policy to tax the price of soy managed to do what rural leaders had been unable to do for decades: unite the rural sector and seat the leaders of groups as disparate as the FAA and the SRA on the same side of the table. This may constrain any future attempts to extend exportoriented populism's economic policies.

In this sense, the shift in agricultural commodity production in Argentina may have political effects beyond facilitating export-oriented populism. By promoting rural unity, soy cultivation may promote the resurgence of rural political power, which has arguably been absent for years. This rural block may provide the foundation for a strong political movement in opposition to the new populism. However, rural political unity may be ephemeral, for once their common cause has been achieved, historical divisions may reemerge and splinter their coalition. One could easily imagine a new cycle of shifting alliances and political instability emerging as a result.

Finally, export-oriented populism is also vulnerable to the traditional scourge of commodity exporters: unstable international prices. Historically, a price increase would promote instability, but today, a serious fall in soybean prices would jeopardize the system of export taxes and wage-goods subsidies. Tax revenue would fall, and pressure from rural producers for the reduction of export tax rates would intensify, further reducing fiscal resources. This would either unravel the system of subsidies that control prices and support real wages, thereby alienating the popular sector, or induce deficit spending, which would bring its own problems. While the rise of modern agriculture may have eliminated one source of political instability in Argentina, it also may have introduced new ones.

\section{Conclusion}

Should the concept of populism be abandoned? Should it now be used restrictively in reference only to historical cases? Can earlier arguments about the links between Argentine populism and the nature of its exports - an argument that appeared to give a compelling account of post-World War II Argentine politics-still help us understand Argentine politics after 2000?

This article has sought to address these questions, arguing that the concept of populism should be retained and that earlier arguments still provide analytic leverage. The switch from beef and wheat production to large-scale soybean cultivation created the conditions for export-oriented populism, which combined broad-based benefits for urban workers and export promotion to support a multi-class coalition under Néstor Kirchner. Historically, Argentina's main exports, beef and wheat, were also the primary consumption goods of the urban working class. Some scholars have argued, particularly O'Donnell (1978), that this linkage increased conflict between the rural and urban sectors, resulting in shifting political coalitions and recurring economic crises. Yet because soybeans are not consumed domestically, the shift in rural production meant that Kirchner could both promote and tax commodity exports, generating fiscal revenue for 
populist programs while not harming real wages or provoking a balance-ofpayments crisis. Export orientation provided the basis for a new variant of Argentine populism.

Populism is not history because it can arise in diverse economic circumstances. In particular, the case of export-oriented populism analyzed here suggests that a more classical form of Latin American populism, featuring a predominantly urban, multi-class alliance and distributing urban wage benefits broadly, can exist despite the constraints imposed by international market forces. It is largely because of integration into international commodity markets that this form of populism is possible. At a more general level, different historical moments or patterns of socioeconomic development may provide populist leaders with distinct policy tools for maintaining a populist coalition. These different strategies, in turn, have implications both for the sustainability of the populist coalition and more generally for political stability.

This article also illustrates how the state can appropriate export rents deriving from an agricultural boom. Existing research on resource wealth and its effects on political stability has focused largely on oil and minerals, but agricultural commodities may have similar effects under certain conditions. Indeed, characteristics of large-scale, mechanized, export agriculture may make it easier to tax than more traditional forms of agriculture. The within-country historical comparison offered here has identified one condition affecting the nature of the resource effect: the linkage between export and domestic markets. This linkage may be more relevant for agricultural commodities, which are more likely to be working-class wage goods than mineral resources are.

Cross-country comparison with other agricultural commodity exporters may suggest additional relevant factors that affect how this type of resource wealth enters the political system. Analysis of Brazil suggests that the state's ability to appropriate resource wealth may shape the resource's political implications, a conclusion that supports key arguments in the resource-curse literature. As the world's largest exporter of raw soybeans, Brazil provides an interesting counterpoint to the case of Argentina: while in Brazil the contemporary commodity boom has been associated with relative political stability and economic prosperity, export-oriented populism has not emerged. Several political factors make export-oriented populism far less likely in Brazil than in Argentina. On an institutional level, the federal tax and revenue-sharing system in Argentina increases the incentives for the central government to tax commodity exports, while the opposite is true in Brazil, where taxes on the circulation of goods - the ICMS - are collected at the state level and export goods are exempt from that tax. On a societal level, the historically fragmented rural sector in Argentina contrasts sharply with the strong, mobilized ruralist group in Brazil, possessing a united congressional front: the bancada ruralista (rural caucus) that has frequently acted as a veto player. It is less politically feasible or advantageous for the central government in Brazil to institute a new system of redistributive taxation of windfall commodity export wealth.

Turning to Paraguay, one may anticipate potentially larger political effects of resource wealth, given the country's greater resource dependence: large-scale soybean production generates roughly half of Paraguay's export revenue. In contrast, politics in Brazil may be less shaped by soy exports due to their lower share of exports there-roughly $10 \%$, less than half the share in Argentina.

Wider comparisons can also help bound the line of my argument. For example, the populism of Chávez in Venezuela, grounded as it is in the export of petroleum, 
involves very different issues. Through cross-country comparisons such as these, as well as through ongoing scrutiny of the Argentine case, the line of analysis advanced here appears a fruitful avenue for deepening our understanding of populism.

Open Access This article is distributed under the terms of the Creative Commons Attribution Noncommercial License which permits any noncommercial use, distribution, and reproduction in any medium, provided the original author(s) and source are credited.

\section{References}

Azcuy AE. La Carne Vacuna Argentina: Historia, Actualidad y Problemas de una Agroindustria Tradicional. Buenos Aires: Imago Mundi; 2007.

Barsky O. Martínez de Hoz y el desarrollo de políticas agrarias en la Argentina. In: Respuesta a Martínez de Hoz, 189-217. Buenos Aires: Imago Mundi, 1991.

Bates RH. Open-Economy Politics: The Political Economy of the World Coffee Trade. Princeton: Princeton UP; 1997.

Bisang R. El desarrollo agropecuario en las últimas décadas: volver a creer. In: Kosacoff B, editor. Crisis, Recuperación y Nuevos Dilemas: La Economía Argentina 2002-2007. Santiago de Chile: CEPAL; 2007. p. 187-260. chap. 7.

Cardoso FH, Faletto E. Dependency and Development in Latin America. Berkeley: U of California P; 1979.

Centeno MA. Blood and Debt: War and the Nation-State in Latin America. State College: Penn State UP; 2002.

Collier D, Norden DL. Strategic choice models of political chance in Latin America. Comp. polit. 1992;24 (2):229-43.

Collier P, Hoeffler A. On economic causes of civil war. Oxf. Econ. Pap. 1998;50:563-73.

Collier RB. Populism. In: Smelser N J, Baltes P B, editors, International Encyclopedia of Social and Behavioral Sciences, 11813-6. Elsevier, 2001.

Collier RB, Collier D. Shaping the Political Arena: Critical Junctures, the Labor Movement, and Regime Dynamics in Latin America. Princeton: Princeton UP; 1991.

De Pablo JC. Precios relativos, distribución del ingreso y planes de estabilización: La experiencia de la Argentina durante 1967-70. Desarro. Econ. 1975;15(57):55-83.

Díaz Alejandro CF. Essays on the Economic History of the Argentine Republic. New Haven: Yale UPp. 1970.

Duejo G. El Capital Monopolista y las Contradicciones Secundarias en la Sociedad Argentina. Buenos Aires: Siglo XXI Argentina; 1973.

Dunning T. Crude Democracy: Natural Resource Wealth and Political Regimes. New York: Cambridge UP; 2008.

Eaton K. Politics Beyond the Capital: The Design of Subnational Institutions in South America. Stanford, CA: Stanford UP; 2004.

Etchemendy S, Collier RB. Down but not out: Union resurgence and segmented neocorporatism in Argentina (2003-2007), Politics and Society 2007;35(3):363-401.

Etchemendy S, Garay C. Between moderation and defiance: The Kirchner government in comparative perspective (2003-2007). In: Levitsky S, Roberts K M, editors, Latin America's Left Turn: Causes and Implications. New York: Cambridge UP, forthcoming.

FAO. http://faostat.fao.org. Accessed 3 May 2007.

Gibson EL. The populist road to market reform: Policy and electoral coalitions in Mexico and Argentina. World Polit 1997;49(3):339-70.

Hirschman AO. A generalized linkage approach to development, with special reference to staples. Economic Development and Cultural Change 1977; 25 (Supplement).

Isham J, Woolcock M, Pritchett L, et al. The varieties of resource experience: Natural resource export structures and the political economy of economic growth. World Bank Econ. Rev 2005;19(2):141-74.

Karl TL. The Paradox of Plenty: Oil Booms and Petro-States. Berkeley: U of California P; 1997.

Knight A. Populism and neo-populism in Latin America, especially Mexico. J. Lat. Am. Stud 1998;30 (2):223-48.

Levitsky S, Murillo MV. Intoduction. In: Levitsky S, Murillo M V, editors. Argentine Democracy: The Politics of Institutional Weakness. University Park, PA: Penn State UP; 2005. p. 1-17. 
Levitsky S, Murillo MV. Argentina: From Kirchner to Kirchner. J. Democr 2008;19(2):16-30.

Mallon RD. Sourrouille JV. Economic Policymaking in a Conflict Society: The Argentine Case. Cambridge: Harvard UP; 1975.

Mazzuca S. Forging states and countries: Metropolises, peripheries, and the emergence of national polities in Latin America, 2003. Paper prepared for Guest Lecture at Instituto Ortega y Gasset, Madrid.

Ministerio de Economía y Producción. Esquema de retenciones móviles para productos primarios y sus derivados, 2008.

Nunes Leal V. Coronelismo: The Municipality and Representative Government in Brazil. New York: Cambridge UP; 1977.

Obschatko ESd. Las etapas del cambio tecnológico. In: Osvaldo B, et al, editor. La Agricultura Pampeana: Transformaciones Productivas y Sociales. Buenos Aires: Fondo de Cultura Económica; 1988. p. 117-36.

O’Donnell G. Modernization and Bureaucratic-Authoritarianism: Studies in South American Politics. Berkeley: Institute of International Studies, University of California, Berkeley; 1973.

O’Donnell G. Estado y alianzas en la Argentina, 1956-1976. Desarro. Econ 1977;16(64):523-54.

O’Donnell G. State and alliances in Argentina, 1956-1976. J. Dev. Stud 1978;15(1):3-33.

O’Donnell G. Delegative democracy. J. Democr 1994;5(1):55-69.

Paige JM. Coffee and Power: Revolution and the Rise of Democracy in Central America. Cambridge: Harvard UP; 1997.

Pierson P. Big, slow-moving, and . . invisible: Macrosocial processes in the study of comparative politics. In: Mahoney J, Rueschemeyer D, editors. Comparative Historical Analysis in the Social Sciences. New York: Cambridge; 2003. p. 177-207.

Roberts KM. Neoliberalism and the transformation of populism in Latin America: The Peruvian case. World polit 1995;48(1):82-116.

Roberts KM. Changing Courses: Parties, Populism, and Political Representation in Latin America's Neoliberal Era. forthcoming.

Rogowski R. Political cleavages and changing exposure to trade. Am. Polit. Sci. Rev 1987;81(4):1121-37.

Rogowski R. Commerce and Coalitions: How Trade Affects Domestic Political Alignments. Princeton, NJ: Princeton UP; 1989.

Schamis HE. Populism, socialism, and democratic institutions. J. Democr 2006;17(2):20-34.

Shifter M. In search of Hugo Chávez. Foreign Affairs 2006;85(3):45-9.

Smith B. Oil wealth and regime survival in the developing world, 1960-1999. Am. J. Polit. Sci 2004;48 (2):232-46.

Smith PH. Politics and Beef in Argentina: Patterns of Conflict and Change. New York: Columbia UP; 1969.

Smith WC. Authoritarianism and the Crisis of the Argentine Political Economy. Stanford, CA: Stanford UP; 1989.

Snyder R. Does lootable wealth breed disorder? A political economy of extraction framework. Comp. Polit. Stud 2006;39(8):943-68.

Snyder R, Bhavnani R. Diamonds, blood, and taxes: A revenue-centered framework for explaining political order. J. Confl. Resolut 2005;49(4):563-97.

Svampa M, Pereyra S. La política de los movimientos piqueteros. In: Schuster F L, Naishtat F S, Nardacchione G, et al, editors. Tomar la Palabra: Estudios sobre Protesta Social y Acción Colectiva en la Argentina Contemporánea. Buenos Aires: Prometeo; 2005. p. 343-64.

Weyland K. Neopopulism and neoliberalism in Latin America: Unexpected affinities. Stud. Comp. Int. Dev. 1996;31(3):3-31.

Weyland K. Clarifying a contested concept: Populism in the study of Latin American politics. Comp. Polit 2001;34(1):1-22.

Weyland K. Neopopulism and neoliberalism in Latin America: How much affinity. Third World Quarterly 2003;24(6):1095-115.

Williams RG. States and Social Evolution: Coffee and the Rise of National Governments in Central America. Chapel Hill: U of North Carolina P; 1994.

Neal P. Richardson is a Ph.D. candidate in political science at the University of California, Berkeley. He researches the political economy of commodity exporting in South America, particularly in Argentina and Brazil. He also studies land conflict in Brazil, as well as quantitative and qualitative research methodology. 